\title{
Tensile bond strength of veneering resins to PEEK: Impact of different adhesives
}

\author{
Bogna STAWARCZYK ${ }^{1}$, Christine KEUL ${ }^{1}$, Florian BEUER ${ }^{1}$, Malgorzata ROOS ${ }^{2}$ and Patrick R. SCHMIDLIN ${ }^{3}$
}

\author{
${ }^{1}$ Department of Prosthodontics, Munich Dental School, Ludwig-Maximilians University Munich, Germany \\ ${ }^{2}$ Division of Biostatistics, Institute of Social and Preventive Medicine, University of Zurich, Switzerland \\ ${ }^{3}$ Clinic of Preventive Dentistry, Periodontology and Cariology, Center of Dental Medicine, University of Zurich, Switzerland \\ Corresponding author, Bogna STAWARCZYK; E-mail: bogna.stawarczyk@med.uni-muenchen.de
}

\begin{abstract}
This study tested tensile bond strength (TBS) between veneering resins and polyetheretherketone (PEEK) after pre-treatment with adhesive systems. Five-hundred-seventy-six PEEK disks were fabricated, air-abraded and divided into six pre-treatment groups $(n=96 /$ group): Z-Prime Plus, Ambarino P60, Monobond Plus, Visio.link, Signum PEEK Bond, and control group without pre-treatment. Each group was divided into three subgroups of different veneering resins $(n=32)$ : Sinfony, GC Gradia and VITA VM LC. After specimen preparation with a bond area of $6.6 \mathrm{~mm}^{2}$, half of each subgroup $(n=16)$ was tested initially, and the other half was thermo-cycled. TBS measurements were analysed by three-way and one-way ANOVA, $t$-test and Weibull statistics. Groups without pre-treatment and groups pre-treated by Z-Prime Plus and Ambarino P60 showed no TBS. Pre-treatment with Monobond Plus increased the TBS values. The highest TBS before and after thermo-cycling between PEEK and all tested veneering resins was observed for groups pre-treated with Visio.link and Signum PEEK Bond.
\end{abstract}

Keywords: PEEK, Polyetheretherketone, Bond strength, Veneering resins

\section{INTRODUCTION}

In general, resin materials for computer aided design (CAD)/computer aided manufacturing (CAM) have become increasingly used in daily clinical practice ${ }^{1}$. Due to their excellent properties, they may be applied as alternative materials to ceramic reconstructions ${ }^{2-5}$. Industrially fabricated $\mathrm{CAD} / \mathrm{CAM}$ resin blocks have better mechanical and optical properties than conventional polymerized resins ${ }^{5-7)}$. The novel highperformance composite PEEK (polyetheretherketone), with its notable mechanical properties ${ }^{8}$, is a polymer from the main group of PAEK (polyaryletherketone). It is biocompatible and chemically stable to nearly all organic and inorganic chemicals ${ }^{8,9}$. Due to its excellent physical and biological properties, this composite material is used both in general medicine and in dentistry as implant, provisional abutment and implant supported bar or clamp material ${ }^{10-13)}$. But PEEK might also be a suitable material for fixed dental prostheses (FDPs), especially in load-bearing areas ${ }^{14)}$ with a reported mean load-bearing capacity of $1,383 \mathrm{~N}$ for 3 -unit PEEK FDPs. A visible deformation of the FDPs was observed at the end of the loading process at approximately $1,200 \mathrm{~N}$ and exceeded, therefore, previous reported mastication forces of up to $600 \mathrm{~N}$ what have been recorded in the posterior region ${ }^{15)}$.

However, there are some aesthetic drawbacks that limit the use of PEEK as full-coverage monolithic restorations. The optical properties of PEEK included low translucency and a greyish color. Therefore a veneering layer, using additional resin composites

Color figures can be viewed in the online issue, which is available at J-STAGE.

Received Jan 9, 2013: Accepted Feb 14, 2013

doi:10.4012/dmj.2013-011 JOI JST.JSTAGE/dmj/2013-011 is required. This adds an additional challenge, as achieving adequate bond strength between veneering resin composites and PEEK surfaces, due to its low surface energy and resistance to surface modification by different chemical treatments ${ }^{16,17)}$, remains difficult. A recent study observed no bond between untreated PEEK surfaces and resin luting cements ${ }^{18}$. Additional etching of the PEEK with sulphuric acid or piranha solution $\left(\mathrm{H}_{2} \mathrm{SO}_{4}\right.$ plus hydrogen peroxide $\left.\mathrm{H}_{2} \mathrm{O}_{2}\right)$ increased the initial bond strength significantly ${ }^{18,19)}$. However, both available studies investigated the bonding properties to resin luting cements without artificial aging. Furthermore no veneering resins were included ${ }^{18,19}$. Considering the risks of these materials as chair-side agent for PEEK frameworks, their application should rather be restricted. Another study assessed the bond strength of a provisional resin to PEEK using different surface treatments and conditioning methods ${ }^{20}$. The authors of the latter study found, that after a 150 days artificial aging period, PEEK air-abraded and primed with Luxatemp Glaze \& Bond resulted in significant higher tensile bond strength values than the other tested pre-treatments. Only one study tested the adhesion between PEEK surfaces and veneering composites ${ }^{14}$. In that study, PEEK surfaces were etched, but additional adhesives were not used.

Temperature changes have considerable influence on the bond strength of the investigated materials. Several studies stated that intraoral thermal changes occur due to the daily routine of eating, drinking ${ }^{21,22)}$ and breathing ${ }^{23)}$. At present there is no systematic standardized procedure for fully mimicking in vitro testing conditions in the laboratory. However, laboratory thermo-cycling does provide a certain standardized and 
reproducible stress to all specimens.

Therefore, the present study investigated the ability of currently available chair-side surface conditioning methods and adhesion promoters to establish adhesion to PEEK, by evaluating bond strength after different pre-treatments to three veneering resins. The hypothesis was that pre-treated PEEK surfaces show higher bond strength to veneering resins compared to untreated surfaces.

\section{MATERIAL AND METHODS}

\section{Specimens preparation}

Five-hundred-seventy-six Dentokeep PEEK specimens (nt-trading, Karlsruhe, Germany) were sectioned (7 $\mathrm{mm} \times 7 \mathrm{~mm} \times 2 \mathrm{~mm}$ ) with a low-speed diamond saw (Well 3241, Well Diamantdrahtsägen, Mannheim, Germany). Specimens were embedded in acrylic resin (ScandiQuick, ScanDia, Hagen, Germany) and then polished from SiC P500 up to P2400 with an automatic polishing device (PlanoPol-2, Struers, Ballerup, Denmark) for $60 \mathrm{~s}$ under water-cooling. After polishing, all specimens were airabraded with $50 \mu \mathrm{m}$ alumina powder (basic Quattro IS, Renfert, Hilzingen, Germany) at $0.2 \mathrm{MPa}$ for $10 \mathrm{~s}$ at $45^{\circ}$ to the air-abraded surface. Before pre-treatment for tensile bond strength (TBS) tests, specimens were ultrasonically cleaned in 80\% ethanol (Otto Fischer, Saarbrücken, Germany) for 5 min and dried on a clean bench at room temperature. Specimens were then divided into six main groups, five of which were pretreated using the following adhesive systems: a) Z-Prime Plus (BISCO, Schaumburg, IL, USA), b) Ambarino P60 (Creamed, Marburg, Germany), c) Monobond Plus (Ivoclar Vivadent, Schaan, Liechtenstein) d) Visio. link (Bredent, Senden, Germany), and e) Signum PEEK Bond I+II (Heraeus Kulzer, Hanau, Germany). The sixth group was not additionally treated and the specimens therein were used as controls. Table 1 gives the manufacturer, the composition and the application steps of the adhesives.

Bonding procedure and preparation for tensile bond strength measurement

Each pre-treatment group was randomly divided into three subgroups $(n=32)$ for the three veneering resins i) Sinfony (3M ESPE, Seefeld, Germany), ii) GC Gradia (GC Europe, Leuven, Belgium) and iii) VITA VM LC (VITA Zahnfabrik, Bad Säckingen, Germany). Acrylic cylinder with an inner diameter of $2.9 \mathrm{~mm}$ were filled with one of the veneering resins and luted to a PEEK surface by means of an alignment apparatus. This apparatus consisted of two parallel guides, a tube holder, a silicone pad and an added weight of $750 \mathrm{~g}$. The use of this device ensured that the tube axis was perpendicular to the bonding surface. Excess veneering resin was removed from the bonding margin using micro-brushes. All materials were applied according to the manufacturer's instructions (Table 1).

Each bonding subgroup was subdivided into two groups of 16 specimens each and stored either in distilled water at $37^{\circ} \mathrm{C}$ for $24 \mathrm{~h}$ or exposed to 10,000 thermal cycles between $5^{\circ} \mathrm{C}$ and $55^{\circ} \mathrm{C}$ (dwell time: $20 \mathrm{~s}$ ) (Thermocycler THE 1100, SD Mechatronik-Westerham, Feldkirchen, Germany).

\section{TBS measurement}

TBS was determined in a Universal Testing Machine (Zwick 1445, Zwick, Ulm, Germany) at a crosshead speed of $5 \mathrm{~mm} / \mathrm{min}$. Specimens were positioned in the jig of the testing machine to the loading direction using a special test configuration, which provided a moment-free axial force application. A collet held the acrylic cylinder while an alignment jig allowed self-centring of the specimen. The jig was attached to the load cell and pulled apart by an upper and lower chain, allowing the whole system to be self-aligning (Fig. 1). The TBS was calculated with the following formula: fracture load/bonding area; N/ $\mathrm{mm}^{2}=\mathrm{MPa}$.

For fracture type analyses, the debonded area was examined by one calibrated and blinded examiner using an optical microscope (Axioskop 2 MAT, Karl Zeiss Mikroskopie, Göttingen, Germany) at 25× magnification. Three failure types were determined and defined: a) adhesive (no composite remnants left on the PEEK surface), b) cohesive failure in PEEK, and c) cohesive failure in veneering resin.

\section{Statistical analyses}

A power analysis had been calculated using nQuery Advisior (Version 6.04.10, Statistical Solutions, Saugaus Mass) prior to performing this study. One pilot study with 7 specimens had been performed with the veneering material Sinfony combined with Monobond Plus to PEEK $(14.5+/-2.6 \mathrm{MPa})$. It was shown that a sample size of 16 in each group would have $95 \%$ power to detect a difference of $27 \%$ in means $(4.5 \mathrm{MPa})$ caused by aging assuming

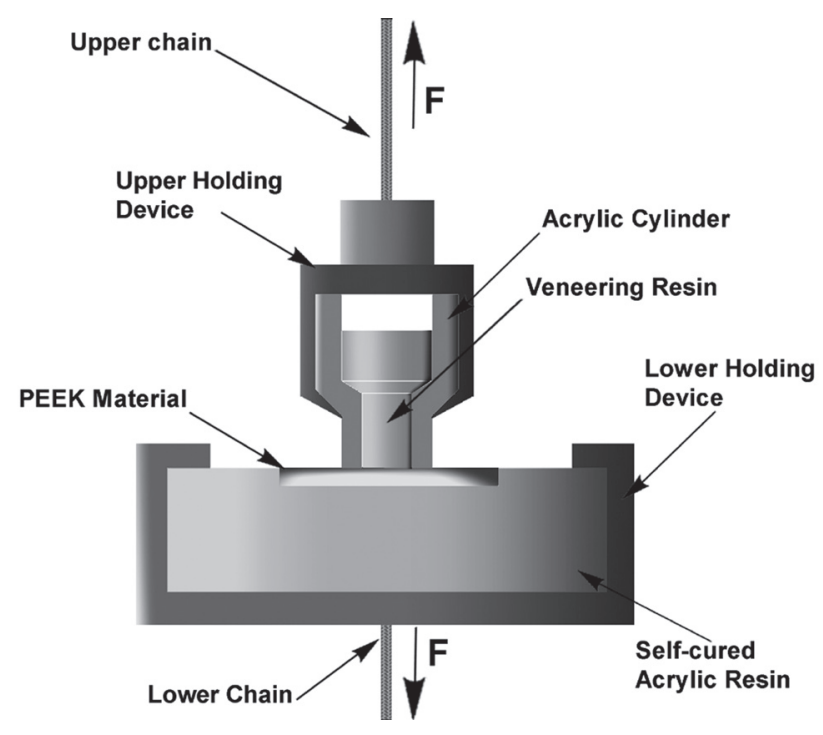

Fig. 1 Tensile bond strength measurement. 
Table 1 Summary of veneering resins and adhesive materials evaluated

\begin{tabular}{|c|c|c|c|c|c|c|}
\hline Materials & $\begin{array}{l}\text { Product } \\
\text { Name }\end{array}$ & Manufacturer & Composition & $\begin{array}{l}\text { Application steps as } \\
\text { recommended by the } \\
\text { manufacturer }\end{array}$ & Lot. No & $\begin{array}{l}\text { Curing light } \\
\text { used* }^{*}\end{array}$ \\
\hline \multirow{5}{*}{ Adhesive } & $\begin{array}{l}\text { Z-Prime } \\
\text { Plus }\end{array}$ & $\begin{array}{l}\text { BISCO, } \\
\text { Schaumburg, } \\
\text { IL, USA }\end{array}$ & $\begin{array}{l}\text { Bis-GMA, } \\
\text { HEMA, ethanol }\end{array}$ & $\begin{array}{l}\text { 1. Apply } 2 \text { coats of } \\
\text { adhesive on PEEK } \\
\text { surface } \\
\text { 2. Dry with an siring } \\
\text { for } 3 \mathrm{~s}\end{array}$ & 1200000769 & - \\
\hline & $\begin{array}{l}\text { Ambarino } \\
\text { P60 }\end{array}$ & $\begin{array}{l}\text { Creamed, } \\
\text { Marburg, } \\
\text { Germany }\end{array}$ & $\begin{array}{c}\text { Dimethacrylate based } \\
\text { on phosphor } \\
\text { acidesters and } \\
\text { phosphon acidesters }\end{array}$ & $\begin{array}{l}\text { Apply on PEEK surface } \\
\text { and leave for } 120 \mathrm{~s}\end{array}$ & 2011004057 & - \\
\hline & $\begin{array}{l}\text { Monobond } \\
\text { Plus }\end{array}$ & $\begin{array}{l}\text { Ivoclar } \\
\text { Vivadent, } \\
\text { Schaan, } \\
\text { Liechtenstein }\end{array}$ & $\begin{array}{c}\text { Silane } \\
\text { methacrylate, } \\
\text { phosphoric acid } \\
\text { methacrylate, } \\
\text { sulphide } \\
\text { methacrylate }\end{array}$ & $\begin{array}{l}\text { 1. Apply with a } \\
\text { microbrush for } 60 \mathrm{~s} \\
\text { 2. Disperse dry } \\
\text { remaining excess } \\
\text { with a strong } \\
\text { stream of air }\end{array}$ & R26669 & - \\
\hline & Visio. link & $\begin{array}{l}\text { Bredent, } \\
\text { Senden, } \\
\text { Germany }\end{array}$ & $\begin{array}{l}\text { MMA, PETIA, } \\
\text { Photoinitiators }\end{array}$ & $\begin{array}{l}\text { 1. Apply adhesive on the } \\
\text { PEEK surface with a } \\
\text { brush } \\
\text { 2. Light cure for } 90 \mathrm{~s}\end{array}$ & 114784 & $\begin{array}{l}\text { Brelux Power } \\
\text { Unit, Bredent }\end{array}$ \\
\hline & $\begin{array}{l}\text { Signum } \\
\text { PEEK } \\
\text { Bond I + II } \\
\text { (experimental } \\
\text { adhesive) }\end{array}$ & $\begin{array}{l}\text { Heraeus } \\
\text { Kulzer, } \\
\text { Hanau, } \\
\text { Germany }\end{array}$ & $\begin{array}{c}\text { Bond I: } \\
\text { bifuctional } \\
\text { molecules based } \\
\text { on phosphoric } \\
\text { acid esters and } \\
\text { thiol compounds } \\
\text { Bond II: } \\
\text { MMA, PMMA, } \\
\text { Photoinitiators }\end{array}$ & $\begin{array}{l}\text { 1. Apply adhesive } 1 \text { on } \\
\text { PEEK surface and leave } \\
\text { for } 10 \mathrm{~s} \\
\text { 2. Apply adhesive } 2 \text { and } \\
\text { light cure for } 90 \mathrm{~s}\end{array}$ & $\begin{array}{l}\text { Bond I: } \\
\text { 010121 } \\
\text { Bond II: } \\
010110\end{array}$ & $\begin{array}{l}\text { HiLitePower, } \\
\text { Heraeus Kulzer }\end{array}$ \\
\hline
\end{tabular}

HEMA;

Octahydro-4,

7-methano- $1 \mathrm{H}$ -

$\begin{array}{cccc}\text { Sinfony } & \text { 3M ESPE, } & \text { indenediyl-bis } & \text { 1. pre-light cure for } 5 \mathrm{~s} \\ \text { (Microhybrid) } & \text { Seefeld, } & \text { (methylene- } & \text { 2. end-polymerizing for } \\ \text { Germany } & \text { diacrylate) } & 16 \text { min under vacuum }\end{array}$

(50 wt\% filler 0.5-

$0.7 \mu \mathrm{m}$ : Sr-Ba-Al-Si

glass, pyrogenic silica)

Veneering

resins

GC Gradia
(Fine hybrid)

VITA VM LC

(Microfilled)
GC Europe, UDMA, EDMA, (75

Leuven, wt\% filler: ceramic,

Belgium prepolymer, $\mathrm{SiO}_{2}$ )

VITA

Zahnfabrik, Bad

Säckingen,

Germany
EDMA, TEGDMA,

DMAEMA, (45-48

wt\% filler $40 \mathrm{~nm}$ :

prepolymerized

splinters, $\mathrm{SiO}_{2}$ )

Pre-polymerizing: Visio Alfa, EM ESPE

476735

End-polymerizing:

Visio Beta Vario, $3 \mathrm{M}$ ESPE

light cure for $5 \mathrm{~min}$

1111111

light cure for $10 \mathrm{~min}$

33941
LABOLIGHT

LV-III,

GC Europe

SPEED

LABOLIGHT,

Hagen \& Werken,

Duisburg,

Germany

* All polymerization lights were chosen according to manufacturer's specific instructions.

MMA: methyl methacrylate, PMMA: polymethyl methacrylate, PETIA: pentaerythritol thiacrylate, Bis-GMA: bisphenol-Adiglycidyl methacrylate, TEGDMA: triethyleneglycol dimethacrylate, HEMA: 2-hydroxyethyl methacrylate, UDMA: urethane dimethacrylate, EDMA: ethylene dimethacrylate, DMAEMA: N,N-dimethylaminoethyl methacrylate. 
that the common standard deviation is $2.6 \mathrm{MPa}$ using two group $t$-test with 0.005 Bonferroni corrected twosided significance level due to 5 pre-treatment groups leading to 10 between groups comparisons.

Descriptive statistics such as mean, standard deviation (SD) and 95\% confidence intervals (95\% CI) were calculated. Normality of data distribution was tested using Kolmogorov-Smirnov and ShapiroWilk tests. Three- and one-way ANOVA followed by Scheffé post-hoc test was used to determine significant differences between the tested groups. Unpaired $t$-test was used to detect the impact of aging. Additionally, the TBS was examined using Weibull statistics. Two-parameter Weibull statistics were estimated by Maximum Likelihood and their 95\% CI were computed. Tests for the equality of the Weibull modulus and the equality of the characteristic fracture load were conducted together with the appropriate Bartletts modified post-hoc test ${ }^{24)}$.

Relative frequencies of failure types together with the corresponding 95\% CI estimated according to the Ciba Geigy tables ${ }^{25)}$, were provided. $P$ values smaller than $5 \%$ were considered to be statistically significant in all tests. The data were analysed using SPSS (Version 20, SPSS INC, Chicago, IL, USA). The Weibull analysis was performed in MINITAB (Version 14, MINITAB, State College, PA, USA).

\section{RESULTS}

The Kolmogorov-Smirnov and Shapiro-Wilk tests indicated no violation of the assumption of normality. The three-way interaction (veneering resin vs. adhesive vs. aging level) showed significant impact on the results $(p<0.001)$. Therefore, the fixed effects of veneering resin, adhesive and aging level cannot be compared directly as the higher order interactions were found to be significant. Consequently, several different analyses were provided and split at levels of veneering resin, adhesive and aging level depending on the hypothesis of interest. Boxplots of TBS measurements in all tested groups are shown in Fig. 2. Table 2 depicts the descriptive statistics (mean, SD, 95\% CI) for TBS values and the results of one-way ANOVA with Scheffé post-hoc test.

In general, Z-Prime Plus or Ambarino P60 as well as the control group resulted in no adhesion to PEEK surface, whereas the use of methyl-methacrylate-based bonding such as Visio.link or Signum PEEK Bond increased the TBS values.

\section{TBS after $24 \mathrm{~h}$ water storage}

The choice of veneering resin showed no impact on the TBS $(p=0.103)$. The pre-treatment with Monobond Plus showed significant lower values for all veneering resins compared to specimens pre-treated with Visio.link or Signum PEEK Bond (Table 2). Within the veneering resin Sinfony group, the PEEK surface pre-treatment with Visio.link (69 MPa) showed significant higher TBS values than with Signum PEEK Bond (48.1 MPa). For GC Gradia and VITA LM LC no significant differences

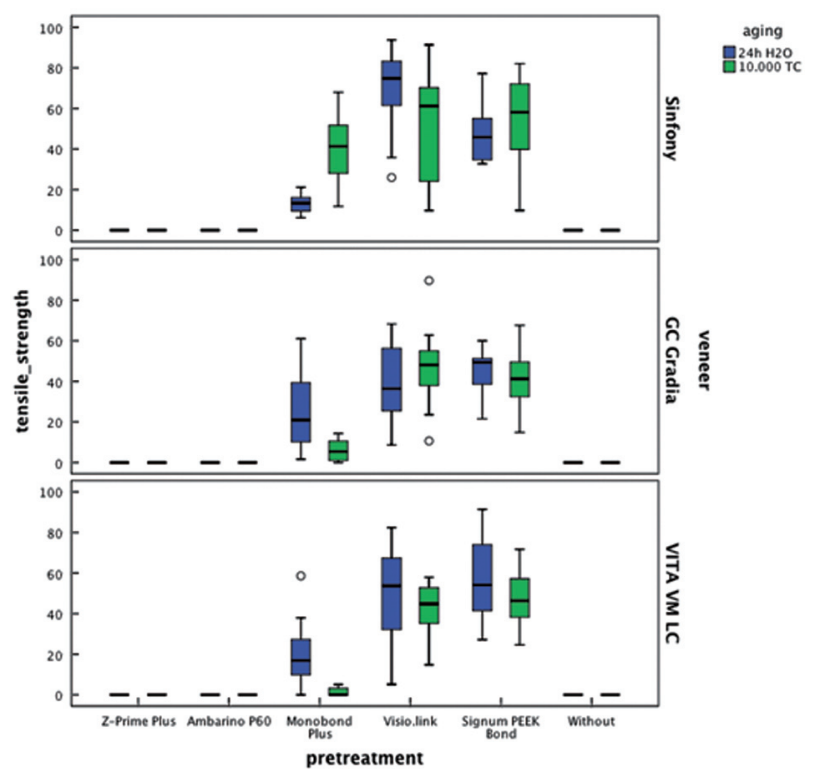

Fig. 2 TBS $[\mathrm{MPa}]$ boxplots of all tested groups.

between treatment with Visio.link (40.0-50.9 MPa) and Signum PEEK Bond (44.5-57.5 MPa) were observed.

TBS after exposure to thermocycling

Monobond Plus combined with Sinfony (40.8 MPa) displayed significantly higher TBS than when combined with GC Gradia (6.1 MPa) or VITA VM LC (1.4 MPa). Within the Sinfony groups, no differences between Monobond Plus, Visio.link and Signum PEEK Bond were observed. Within GC Gradia and VITA VM LC groups, Visio.link (42.2-47.0 MPa) and Signum PEEK Bond (41.3-47.1 MPa) showed significant higher TBS compared to Monobond Plus (1.4-6.1 MPa).

\section{Impact of thermocycling}

Thermo-cycling showed an impact on all veneering resins combined with Monobond Plus. Within the Monobond Plus pre-treatment group, the negative impact of thermocycling on the TBS was significant for GC Gradia $(p=0.001)$ and for VITA VM LC $(p<0.001)$. Sinfony combined with Monobond Plus $(p<0.001)$ showed significantly higher values for TBS after thermocycling. For all remaining groups no impact of thermocycling was observed $(p=0.068-0.483)$.

\section{Weibull statistics}

The Weibull statistics are presented in Table 3. In general, pre-treatment with Visio.link (2.97-4.64) or Signum PEEK Bond (2.62-5.46) showed significant higher Weibull Moduli compared to specimens treated with Monobond Plus (0.26-3.35). The control groups as well as the pre-treated groups using Z-Prime Plus and Ambarino P60 showed no bond and therefore both Weibull parameter such as scale and shape (modulus) could not be computed. 
Table 2 Mean (SD) and 95\% confidence interval of TBS [MPa] of three different veneering resins on air-abraded and subsequently pretreated PEEK surfaces

\begin{tabular}{|c|c|c|c|c|c|c|}
\hline \multirow{2}{*}{ Pre-treatment methods } & \multicolumn{2}{|c|}{ Sinfony } & \multicolumn{2}{|c|}{ GC Gradia } & \multicolumn{2}{|c|}{ VITA VM LC } \\
\hline & Mean (SD) & $95 \% \mathrm{CI}$ & Mean (SD) & $95 \% \mathrm{CI}$ & Mean (SD) & $95 \% \mathrm{CI}$ \\
\hline \multicolumn{7}{|c|}{ TBS tested $24 \mathrm{~h}$ after specimens preparation } \\
\hline Z-Prime Plus & $0^{\mathrm{a}}$ & - & $0^{\mathrm{a}}$ & - & $0^{\mathrm{a}}$ & - \\
\hline Ambarino P60 & $0^{\mathrm{a}}$ & - & $0^{\mathrm{a}}$ & - & $0^{\mathrm{a}}$ & - \\
\hline Monobond Plus & $13.4(4.6)^{\mathrm{b}}$ & $(10.8 ; 15.9)$ & $26.0(19.3)^{\mathrm{b}}$ & $(15.6 ; 36.4)$ & $20.1(15.1)^{\mathrm{b}}$ & $(12.0 ; 28.2)$ \\
\hline Visio.link & $69.0(19.6)^{\mathrm{d}}$ & $(58.4 ; 79.5)$ & $40.0(18.8)^{\mathrm{bc}}$ & $(30.0 ; 50.1)$ & $50.9(21.4)^{\mathrm{c}}$ & $(39.4 ; 62.4)$ \\
\hline Signum PEEK Bond I+II & $48.1(13.8)^{\mathrm{c}}$ & $(40.6 ; 55.5)$ & $44.5(10.5)^{\mathrm{c}}$ & $(38.7 ; 50.1)$ & $57.5(19.6)^{\mathrm{c}}$ & $(47.0 ; 68.0)$ \\
\hline without pre-treatment & $0^{\mathrm{a}}$ & - & $0^{\mathrm{a}}$ & - & $0^{\mathrm{a}}$ & - \\
\hline \multicolumn{7}{|c|}{ TBS tested after thermal aging ( 10,000 cycles) } \\
\hline Z-Prime Plus & $0^{\mathrm{a}}$ & - & $0^{\mathrm{a}}$ & - & $0^{\mathrm{a}}$ & - \\
\hline Ambarino P60 & $0^{\mathrm{a}}$ & - & $0^{\mathrm{a}}$ & - & $0^{\text {a }}$ & - \\
\hline Monobond Plus & $40.8(15.1)^{\mathrm{b}}$ & $(32.6 ; 48.9)$ & $6.1(5.2)^{\mathrm{b}}$ & $(3.2 ; 9.0)$ & $1.4(1.9)^{\mathrm{b}}$ & $(0.32 ; 2.4)$ \\
\hline Visio. link & $53.3(26.7)^{\mathrm{b}}$ & $(39.0 ; 67.6)$ & $47.0(17.7)^{\mathrm{c}}$ & $(37.4 ; 56.5)$ & $42.2(13.1)^{\mathrm{c}}$ & $(35.1 ; 49.2)$ \\
\hline Signum PEEK Bond I+II & $54.3(23.1)^{\mathrm{b}}$ & $(41.8 ; 66.6)$ & $41.3(14.5)^{\mathrm{c}}$ & $(33.4 ; 49.1)$ & $47.1(12.9)^{\mathrm{c}}$ & $(40.1 ; 54.0)$ \\
\hline without pre-treatment & $0^{\mathrm{a}}$ & - & $0^{\mathrm{a}}$ & - & $0^{\mathrm{a}}$ & - \\
\hline
\end{tabular}

${ }^{\text {abcd }}$ Different letters show significant differences between the methods of pre-treatment among one veneering resin and PEEK surface.

\section{Failure types}

The relative frequency of the failure types with $95 \% \mathrm{CI}$ of all failure types, are shown as percentages in Table 4. For all veneering resins, the combination with Z-Prime Plus, Ambarino P60, Monobond Plus and the control groups without pre-treatment showed predominantly adhesive failures. In the groups using Visio.link or Signum PEEK Bond cohesive failures in resin composite were predominantly detected. No cohesive failure in PEEK substrate was found.

\section{DISCUSSION}

The effective and durable bonding to PEEK is a prerequisite for its use in dentistry as a definitive prosthetic material. This study assessed the TBS between different veneering resins and PEEK after pre-treatment with different primers and adhesives. PEEK without pre-treatment was unable to create any adherence to the definitive veneering composite materials, despite the fact that surfaces were roughened beforehand. Also pre-treatment with Z-Prime Plus and Ambarino P60 showed no TBS, whereas pretreatment with Monobond Plus slightly increased TBS values. Only Visio.link and Signum PEEK Bond I+II significantly increased the bond strength between PEEK and the veneering resins before and after aging.
Therefore, the study hypothesis is valid for Visio.link and Signum PEEK Bond I+II groups, but not for Z-Prime Plus and Ambarino P60 groups.

The present study did not include highly polished PEEK specimens aiming to focus on chemical interactions. Instead, all surfaces were air-abraded to create a standardized surface with some micromechanical retentions. In a previous study, no adhesion to air-abraded or even silica-coated PEEK was achieved using self-adhesive resin luting cement ${ }^{18)}$. However the application of an unfilled resin and a fine hybrid resin composite resulted in initial bond strengths of 11.5-13.5 MPa. Additional acid-etching with sulfuric acid resulted in increased initial bond strengths up to 21.4 $\mathrm{MPa}^{19)}$. No thermo-cycling was performed in the latter studies.

Storage and thermo-cycling are the most often used artificial aging methods for simulating fatigue in laboratory testing of bonding durability ${ }^{20,26)}$. This minimal requirement of simulating oral conditions seems necessary before clinical recommendations can be provided, even with caution. Artificial aging by the procedure of thermo-cycling may act in two different ways on the TBS. On one side it may lead to an increase of the bond strength, caused by the post-polymerisation in the contact area of the PEEK surface, the adhesive and the veneering cement. On the other side, the thermal 
Table 3 Weibull modulus (shape) with 95\% confidence interval and characteristic TBS (scale) [MPa] of three different veneering resins on air-abraded and subsequently pretreated PEEK surfaces

\begin{tabular}{|c|c|c|c|c|c|c|}
\hline \multirow[b]{2}{*}{ Pre-treatment methods } & \multicolumn{2}{|c|}{ Sinfony } & \multicolumn{2}{|c|}{ GC Gradia } & \multicolumn{2}{|c|}{ VITA VM LC } \\
\hline & $\begin{array}{c}\text { Scale } \\
(95 \% \text { CI })\end{array}$ & $\begin{array}{l}\text { Shape } \\
(95 \% \mathrm{CI})\end{array}$ & $\begin{array}{c}\text { Scale } \\
(95 \% \mathrm{CI})\end{array}$ & $\begin{array}{l}\text { Shape } \\
(95 \% \text { CI })\end{array}$ & $\begin{array}{c}\text { Scale } \\
(95 \% \text { CI })\end{array}$ & $\begin{array}{l}\text { Shape } \\
(95 \% \text { CI })\end{array}$ \\
\hline \multicolumn{7}{|c|}{ TBS tested $24 \mathrm{~h}$ after specimens preparation } \\
\hline Z-Prime Plus & - & - & - & - & - & - \\
\hline Ambarino P60 & - & - & - & - & - & - \\
\hline Monobond Plus & $\begin{array}{c}15.0 \\
(12.7 ; 17.5)^{\mathrm{b}}\end{array}$ & $\begin{array}{c}3.35 \\
(2.26 ; 4.94)^{\mathrm{a}}\end{array}$ & $\begin{array}{c}27.6 \\
(18.0 ; 42.1)^{\mathrm{b}}\end{array}$ & $\begin{array}{c}1.22 \\
(0.8 ; 1.85)^{\mathrm{a}}\end{array}$ & $\begin{array}{c}20.0 \\
(11.8 ; 33.5)^{\mathrm{b}}\end{array}$ & $\begin{array}{c}0.97 \\
(0.62 ; 1.49)^{\mathrm{a}}\end{array}$ \\
\hline Visio.link & $\begin{array}{c}75.8 \\
(67.7 ; 84.6)^{\mathrm{d}}\end{array}$ & $\begin{array}{c}4.64 \\
(3.02 ; 7.1)^{\mathrm{a}}\end{array}$ & $\begin{array}{c}45.2 \\
(36.2 ; 56.1)^{\mathrm{c}}\end{array}$ & $\begin{array}{c}2.37 \\
(1.56 ; 3.58)^{\mathrm{a}}\end{array}$ & $\begin{array}{c}64.3 \\
(55.0 ; 75.1)^{\mathrm{c}}\end{array}$ & $\begin{array}{c}3.34 \\
(2.26 ; 4.91)^{\mathrm{b}}\end{array}$ \\
\hline Signum PEEK Bond I+II & $\begin{array}{c}53.2 \\
(46.2 ; 61.1)^{\mathrm{c}}\end{array}$ & $\begin{array}{c}3.79 \\
(2.63 ; 5.46)^{\mathrm{a}}\end{array}$ & $\begin{array}{c}48.4 \\
(44.0 ; 53.2)^{\mathrm{c}}\end{array}$ & $\begin{array}{c}5.46 \\
(3.62 ; 8.21)^{\mathrm{b}}\end{array}$ & $\begin{array}{c}56.8 \\
(46.6 ; 69.1)^{\mathrm{c}}\end{array}$ & $\begin{array}{c}2.62 \\
(1.71 ; 3.98)^{\mathrm{b}}\end{array}$ \\
\hline without pre-treatment & - & - & - & - & - & - \\
\hline \multicolumn{7}{|c|}{ TBS tested after thermal aging $(10,000$ cycles $)$} \\
\hline Z-Prime Plus & - & - & - & - & - & - \\
\hline Ambarino P60 & - & - & - & - & - & - \\
\hline Monobond Plus & $\begin{array}{c}45.7 \\
(38.5 ; 53.9)^{\mathrm{b}}\end{array}$ & $\begin{array}{c}3.11 \\
(2.09 ; 4.61)^{\mathrm{a}}\end{array}$ & $\begin{array}{c}3.9 \\
(1.1 ; 12.6)^{\mathrm{b}}\end{array}$ & $\begin{array}{c}0.44 \\
(0.26 ; 0.69)^{\mathrm{a}}\end{array}$ & $\begin{array}{c}0.17 \\
(0.01 ; 1.20)^{\mathrm{b}}\end{array}$ & $\begin{array}{c}0.26 \\
(0.16 ; 0.39)^{\mathrm{a}}\end{array}$ \\
\hline Visio.link & $\begin{array}{c}60.1 \\
(47.3 ; 76.1)^{\mathrm{c}}\end{array}$ & $\begin{array}{c}2.17 \\
(1.40 ; 3.32 ; 67.6)^{\mathrm{a}}\end{array}$ & $\begin{array}{c}46.1 \\
(44.0 ; 62.61)^{\mathrm{c}}\end{array}$ & $\begin{array}{c}2.9 \\
(2.0 ; 4.24)^{\mathrm{b}}\end{array}$ & $\begin{array}{c}46.6 \\
(41.0 ; 52.9)^{\mathrm{c}}\end{array}$ & $\begin{array}{c}4.1 \\
(2.66 ; 6.21)^{\mathrm{b}}\end{array}$ \\
\hline Signum PEEK Bond I+II & $\begin{array}{c}60.7 \\
(50.1 ; 73.5)^{\mathrm{c}}\end{array}$ & $\begin{array}{c}2.68 \\
(1.72 ; 4.15)^{\mathrm{a}}\end{array}$ & $\begin{array}{c}46.1 \\
(39.2 ; 54.0)^{\mathrm{c}}\end{array}$ & $\begin{array}{c}3.3 \\
(2.20 ; 4.83)^{\mathrm{b}}\end{array}$ & $\begin{array}{c}51.6 \\
(45.6 ; 58.8)^{\mathrm{c}}\end{array}$ & $\begin{array}{c}4.15 \\
(2.83 ; 6.05)^{\mathrm{b}}\end{array}$ \\
\hline without pre-treatment & - & - & - & - & - & - \\
\hline
\end{tabular}

${ }^{\text {abcd }}$ Different letters show significant differences between the methods of pre-treatment among one veneering resin and PEEK surface.

stress may lead to mechanical stress of the bonding area caused by different volumetric changes of the concerned materials. Both phenomena were observed for the pre-treatment with Monobond Plus. Whereas thermocycling leads to significant higher TBS for the veneering resin Sinfony (13.4/40.8 MPa), a significant decrease of TBS was observed for GC Grandia (26.0/6.1 MPa) and VITA VM LC (20.1/1.4 MPa). Thermo-cycling after pretreatment with Visio.link and Signum PEEK Bond I+II showed no impact on TBS.

The choice of the tested adhesives was based on recommendations of the PEEK manufacturer. The user's manual suggests primarily the use of Visio.link or Ambarino P60 to create sufficient bond strength between PEEK surface and different veneering resin cements. The latter - interestingly — failed to create any bonding potential. The other successfully tested material, Signum PEEK Bond represents an experimental adhesive for bond to PEEK and has therefore also been included in this study.
In a previous study, it could be shown that the application of an adhesive prior to the application of a self-adhesive resin cement was able to establish bonding even after thermo-cycling and without sulphuric acid application $^{27)}$. It seems that MMA monomers are important contributors of increased bond strength between PEEK and veneering resins. This was also supported by the study of Kern \& Lehmann, which showed that a durable bonding to PEEK could only be achieved using the multifunctional methacrylate containing resin varnish (Luxatemp Glaze \& Bond) on air-abraded surfaces to create substantial chemical bonding to $\mathrm{PEEK}^{20}$. This study also concluded that the use of phosphate monomer containing primer on airabraded PEEK did not result in any adhesion.

In the current study the air-abraded $(50 \mu \mathrm{m}, 0.2$ $\mathrm{MPa}$ ) PEEK surfaces conditioned with adhesive systems Visio.link (40.0-69.0 MPa) or Signum PEEK Bond I +II (41.3-57.5 MPa) showed similar or higher TBS results compared to those obtained with other framework 
Table 4 Failure types, relative frequencies and 95\% confidence interval for all tested groups [\%]

\begin{tabular}{|c|c|c|c|c|c|c|}
\hline \multirow[b]{2}{*}{ Pre-treatment methods } & \multicolumn{2}{|c|}{ Sinfony } & \multicolumn{2}{|c|}{ GC Gradia } & \multicolumn{2}{|c|}{ VITA VM LC } \\
\hline & $\begin{array}{l}\text { adhesive - } \\
\text { relative } \\
\text { frequencies, } \\
\quad 95 \% \mathrm{CI}\end{array}$ & $\begin{array}{c}\text { cohesive } \\
\text { veneering } \\
\text { resin - } \\
\text { relative } \\
\text { frequencies, } \\
95 \% \mathrm{CI}\end{array}$ & $\begin{array}{c}\text { adhesive - } \\
\text { relative } \\
\text { frequencies, } \\
95 \% \text { CI }\end{array}$ & $\begin{array}{c}\text { cohesive } \\
\text { veneering } \\
\text { resin - } \\
\text { relative } \\
\text { frequencies, } \\
95 \% \mathrm{CI}\end{array}$ & $\begin{array}{c}\text { adhesive - } \\
\text { relative } \\
\text { frequencies, } \\
95 \% \mathrm{CI}\end{array}$ & $\begin{array}{c}\text { cohesive } \\
\text { veneering } \\
\text { resin - } \\
\text { relative } \\
\text { frequencies, } \\
95 \% \mathrm{CI}\end{array}$ \\
\hline \multicolumn{7}{|c|}{ TBS tested $24 \mathrm{~h}$ after specimens preparation } \\
\hline Z-Prime Plus & $100(79 ; 100)$ & $0(0 ; 21)$ & $100(79 ; 100)$ & $0(0 ; 21)$ & $100(79 ; 100)$ & $0(0 ; 21)$ \\
\hline Ambarino P60 & $100(79 ; 100)$ & $0(0 ; 21)$ & $100(79 ; 100)$ & $0(0 ; 21)$ & $100(79 ; 100)$ & $0(0 ; 21)$ \\
\hline Monobond Plus & $100(79 ; 100)$ & $0(0 ; 21)$ & $94(69 ; 100)$ & $6(0.1 ; 31)$ & $94(69 ; 100)$ & $6(0.1 ; 31)$ \\
\hline Visio.link & $0(0 ; 21)$ & $100(79 ; 100)$ & $44(19 ; 71)$ & $56(29 ; 81)$ & $75(47 ; 93)$ & $25(7 ; 53)$ \\
\hline Signum PEEK Bond I+II & $6(0.1 ; 31)$ & $94(69 ; 100)$ & $13(1 ; 39)$ & $88(61 ; 99)$ & $0(0 ; 21)$ & $100(79 ; 100)$ \\
\hline without pre-treatment & $100(79 ; 100)$ & $0(0 ; 21)$ & $100(79 ; 100)$ & $0(0 ; 21)$ & $100(79 ; 100)$ & $0(0 ; 21)$ \\
\hline \multicolumn{7}{|c|}{ TBS tested after thermal aging ( 10,000 cycles) } \\
\hline Z-Prime Plus & $100(79 ; 100)$ & $0(0 ; 21)$ & $100(79 ; 100)$ & $0(0 ; 21)$ & $100(79 ; 100)$ & $0(0 ; 21)$ \\
\hline Ambarino P60 & $100(79 ; 100)$ & $0(0 ; 21)$ & $100(79 ; 100)$ & $0(0 ; 21)$ & $100(79 ; 100)$ & $0(0 ; 21)$ \\
\hline Monobond Plus & $44(19 ; 71)$ & $56(29 ; 81)$ & $100(79 ; 100)$ & $0(0 ; 21)$ & $100(79 ; 100)$ & $0(0 ; 21)$ \\
\hline Visio.link & $38(15 ; 65)$ & $63(35 ; 85)$ & $6(0.1 ; 31)$ & $94(69 ; 100)$ & $25(7 ; 53)$ & $75(47 ; 93)$ \\
\hline Signum PEEK Bond I+II & $25(7 ; 53)$ & $75(47 ; 93)$ & $25(7 ; 53)$ & $75(47 ; 93)$ & $6(0.1 ; 31)$ & $94(69 ; 100)$ \\
\hline without pre-treatment & $100(79 ; 100)$ & $0(0 ; 21)$ & $100(79 ; 100)$ & $0(0 ; 21)$ & $100(79 ; 100)$ & $0(0 ; 21)$ \\
\hline
\end{tabular}

materials tested in previous studies. Kern \& Lehmann ${ }^{20)}$ tested air-abraded (110 $\mu \mathrm{m}, 0.28$ bar) PEEK pre-treated with Glaze \& Bond and cemented with Luxatemp Fluorescence and found TBS values between 12.9-15.0 $\mathrm{MPa}$. In this study the measured TBS after application of Visio.link or Signum PEEK Bond I +II was significantly higher by factor two. All other combinations in the Kern \& Lehmann study showed no bond. Hallmann et al. ${ }^{19)}$ investigated the impact of etching the PEEK surfaces with piranha solution on the bond strength to resin cements. The TBS results ranged between 8.6 and 21.4 $\mathrm{MPa}$. Tensile bond strength on air-abraded zirconia (50 $\mu \mathrm{m}, 5$ bar) adhesively cemented ranged from 21.9-42.8 $\mathrm{MPa}^{28)}$ and is comparable to the results in this study. In contrast, the bonding to etched lithium disilicate ceramic using a luting resin (Multilink Automix) presented TBS of 37.9-49.5 $\mathrm{MPa}^{29)}$. The TBS to alloy frameworks in combination with adhesives and luting cements was reported to be in the range of $17-20 \mathrm{MPa}^{30)}$. All of this studies found investigated the bond strength to resin cements. No results for TBS combined with veneering resins were found. Therefore, it can be concluded, that the TBS after application of Visio.link or Signum PEEK Bond I +II and bonding showed excellent results.

Bond strength tests assess the quality of adhesion.
Although this study could not replicate all individual variations of the intraoral conditions, it may help in determining reliable bond formation between PEEK materials and veneering resins in dentistry. In conclusion, the bonding properties of the veneering resins to the PEEK surface depend on the selective assortment of the pre-treatment method and the veneering resin, and can therefore be recommended for further clinical studies. However, the complexity of the chemistry of the different bonding agents, as well as possible combinations, makes general recommendations difficult. The manufacturers' instructions for veneering PEEK frameworks should provide more details and focus on scientifically proven materials.

\section{ACKNOWLEDGMENTS}

The authors would like to express their gratefulness to nt-trading, 3M ESPE, VITA Zahnfabrik, Creamed, Ivoclar Vivadent, Bredent and Heraeus Kulzer for supporting this study with materials.

\section{REFERENCES}

1) Miyazaki T, Hotta $Y$, Kunii J, Kuriyama S, Tamaki Y. 
A review of dental CAD/CAM: current status and future perspectives from 20 years of experience. Dent Mater J 2009; 28: 44-56.

2) Magne P, Schlichting LH, Maia HP, Baratieri LN. In vitro fatigue resistance of $\mathrm{CAD} / \mathrm{CAM}$ resin composite and ceramic posterior occlusal veneers. J Prosthet Dent 2010; 104: 149157.

3) Stawarczyk B, Sener B, Trottmann A, Roos M, Özcan M, Hämmerle C. Discoloration of manually fabricated resins and industrially fabricated $\mathrm{CAD} / \mathrm{CAM}$ blocks versus glassceramic: Effect of storage media, duration, and subsequent polishing. Dent Mater J 2012; 31: 377-383.

4) Stawarczyk B, Özcan M, Trottmann A, Schmutz F, Roos M, Hämmerle C. Two-body wear rate of CAD/CAM resin blocks and their enamel antagonists. J Prosthet Dent (in press).

5) Stawarczyk B, Ender A, Trottmann A, Özcan M, Fischer J, Hämmerle CHF. Load-bearing capacity of CAD/CAM milled polymeric three-unit fixed dental prostheses: Effect of aging regimens. Clin Oral Investig 2012; 16: 1669-1677.

6) Göncü Başaran E, Ayna E, Vallittu PK, Lassila LVJ. Loadbearing capacity of handmade and computer-aided designcomputer-aided manufacturing-fabricated three-unit fixed dental prostheses of particulate filler composite. Acta Odontol Scand 2011; 69:144-150.

7) Alt V, Hannig M, Wöstmann B, Balkenhol M. Fracture strength of temporary fixed partial dentures: CAD/CAM versus directly fabricated restorations. Dent Mater 2011; 27: 339-347.

8) Kurtz SM, Devine JN. PEEK biomaterials in trauma, orthopedic, and spinal implants. Biomaterials 2007; 28: 48454869.

9) Toth JM, Wang M, Estes BT, Scifert JL, Seim HB 3rd, Turner AS. Polyetheretherketone as a biomaterial for spinal applications. Biomaterials 2006; 27: 324-334.

10) Tetelman ED, Babbush CA. A new transitional abutment for immediate aestehetics and function. Implant Dent 2008; 17: 51-58.

11) Santing HJ, Meijer HJ, Raghoebar GM, Ozcan M. Clin Implant Dent Relat Res 2012; 14: 882-889.

12) Bayer S, Komor N, Kramer A, Albrecht D, Mericske-Stern R, Enkling N. Clin Oral Implants Res 2012; 23: 1377-1384.

13) Tannous F, Steiner M, Shahin R, Kern M. Retensive forces and fatique reistance of thermoplastic resin clasps. Dent Mater 2012; 28: 273-278.

14) Stawarczyk B, Beuer F, Wimmer T, Jahn D, Sener B, Roos M, Schmidlin PR. PEEK -A suitable material for fixed dental prostheses? J Biomed Mater Res B Appl Biomater 2012; submitted.

15) Behr M, Rosentritt M, Lang R, Handel G. Glass fiberreinforced abutments for dental implants. A pilot study. Clin Oral Implants Res 2001; 12: 174-178.

16) Noiset O, Schneider YJ, Marchand-Brynaert J. Adhesion and growth of CaCo2 cells on surface-modified PEEK substrata. J Biomater Sci Polym Ed 2000; 11: 767-786.

17) Ohl A, Schröder K, Keller D, Meyer-Plath A, Bienert H, Husen B, Rune GM. Chemical micropatterning of polymeric cell culture substrates using low-pressure hydrogen gas discharge plasmas. J Mater Sci Mater Med 1999; 10: 747 754 .

18) Schmidlin PR, Stawarczyk B, Wieland M, Attin T, Hammerle $\mathrm{CH}$, Fischer J. Effect of different surface pre-treatment and luting materials on shear bond strength to PEEK. Dent Mater 2010; 26: 553-559.

19) Hallmann L, Mehl A, Sereno N, Hämmerle CHF. The improvement of adhesive properties of PEEK through different pre-treatments. Appl Surf Sci 2012; 258: 72137218.

20) Kern M, Lehmann F. Influence of surface conditioning on bonding to polyetheretherketon (PEEK). Dent Mater 2012; 28: 1280-1283.

21) Palmer DS, Barco MT, Billy EJ. Temperature extremes produced orally by hot and cold liquids. J Prosthet Dent 1992; 67: 325-327.

22) Longman CM, Pearson CJ. Variation in temperature of the oral cavity during the imbition of hot and cold fluids [special issue]. J Dent Res 1984; 63: 521.

23) Boehm RF. Thermal environment of teeth during open mouth respiration. J Dent Res 1972; 51: 75-78.

24) Roos M, Stawarczyk B. Evaluation of bond strength of resin cements using different general-purpose statistic software packages for two-parameter Weibull statistics. Dent Mater 2012; 28: e76-88.

25) Wissenschaftliche Tabellen Geigy, Teilband Statistik, 8. Auflage, Basel, 1980 CIBA-GEIGY Limited, Basel, Switzerland.

26) Wegner SM, Gerdes W, Kern M. Effect of different artificial aging conditions on ceramic/composite bond strength. Int J Prosthodont 2002; 15: 267-272.

27) Stawarczyk B, Bähr N, Beuer F, Wimmer T, Eichberger M, Gernet W, Jahn D, Schmidlin PR. Influence of plasma pretreatment on shear bond strength of self-adhesive resin cements to polyetheretherketone. Clin Oral Investig 2012; submitted.

28) Attia A, Kern M. Effect of cleaning methods after reducedpressure air-abrasion on bonding to zirconia ceramics. J Adhes Dent 2011; 13: 561-567.

29) Klosa K, Wolfart S, Lehmann F, Wenz HJ, Kern M. The effect of storage conditions, contamination modes and cleaning procedures on the resin bond strength to lithium disilicate ceramic. J Adhes Dent 2009; 11: 127-135.

30) Azimian F, Klosa K, Kern M. Evaluation of a new universal primer for ceramic and alloys. J Adhes Dent 2012; 14: 275282. 